\title{
Competition and educational quality: evidence from the Netherlands
}

\author{
Elbert Dijkgraaf • Raymond H. J. M. Gradus • \\ J. Matthijs de Jong
}

Published online: 8 July 2012

(C) The Author(s) 2012. This article is published with open access at Springerlink.com

\begin{abstract}
Little evidence is available for the effect of competition on educational quality as only a few countries allow large-scale competition. In the Netherlands, free parental choice has been present since the beginning of the twentieth century and can be characterized as a full voucher program with $100 \%$ funding. Based on micro panel data for the Netherlands, we show that there is a relation between competition and educational outcomes in secondary education, but that it is often negative and small, sometimes insignificant but never positive. This effect is larger for small and medium-sized schools and for schools that do not have a Protestant or Catholic denomination.
\end{abstract}

Keywords Competition · Private schools $\cdot$ Scale $\cdot$ Quality $\cdot$ Secondary education JEL Classification $\mathrm{H} 70 \cdot \mathrm{I} 20$

Electronic supplementary material The online version of this article (doi:10.1007/s10663-0129195-6) contains supplementary material, which is available to authorized users.

\section{E. Dijkgraaf $(\bowtie)$}

Erasmus School of Economics, Tinbergen Institute, Room H 8-21, P.O. Box 1738, 3000 DR Rotterdam, The Netherlands

e-mail: dijkgraaf@ese.eur.nl

R. H. J. M. Gradus

Research Institute for the CDA and Faculty of Economics and Business Administration, VU University Amsterdam, De Boelelaan 1105, Room 1E-66, 1081 HV Amsterdam, The Netherlands e-mail: rgradus@xs4all.nl

J. M. de Jong SEOR and Erasmus School of Economics, Erasmus University Rotterdam, Room H 7-25, P.O. Box 1738, 3000 DR Rotterdam, The Netherlands e-mail: jmdejong@ese.eur.nl 


\section{Introduction}

The literature discusses whether competition between schools increases the quality of educational outcomes. Friedman (1962) claimed that school choice policies promise to align the incentives of school management with demand. Positive effects on educational outcomes can occur if students choose schools with higher quality levels. This increases the incentives for schools to invest in the quality of the primary process to improve educational outcomes. From a theoretical point of view, a negative effect of competition on quality is also possible. In practice, many other characteristics influence school choice. If, for instance, students look more at their friends' choices or at the attractiveness of sports programs, the link between school choice and quality might be very different. Schools might choose to invest time and money in characteristics appreciated by potential students which are not related to the (direct) quality of education and might see greater benefits in marketing themselves to prospective students than in improving their programs. In this case, the effect of competition on educational outcomes might become negative since less time and money are available for the primary process. In addition, measuring and interpreting quality might not be straightforward and costless for students and their parents. Which effect dominates is a matter for empirical analysis.

In many cross-country studies differences in economic growth have been related to school attainment, years of schooling and school autonomy and decentralization and there is evidence for a significant positive relation between (cognitive) skills and economic growth [see for an overview Hanushek and Woessmann (2011)]. In addition, cross-country comparison indicates that students in countries with a larger share of privately managed schools (and public school funding) tend to perform better on average Woessmann (2009) and Maslowski et al. (2007). Recent macro evidence corroborates the conclusion that this seems due to a causal effect of private-sector competition measured by the share of students attending privately operated schools (West and Woessmann 2009). Nevertheless, the share of private students is only a weak proxy for competition.

In addition, based on panel data empirical analysis of the effect of competition on the quality of educational outcomes is scarce due to the absence of micro data and large-scale competition in many countries. A few examples make this clear. Hoxby (2000) uses the concept of Tiebout choice, that parents choose between US school districts based on the quality differences between schools, to test this hypothesis. Her result suggests that competition enhances quality for elementary and secondary education. However, Rothstein (2007) shows that her results are sensitive to the construction of the competition variables and claims that alternative constructions yield insignificant results. Moreover, Rothstein (2007, p. 2034) finds that Hoxby's specification is subject to selection bias because the sample excludes private school students. These criticisms are disputed in Hoxby (2007), but the discussion is still unsettled. More important seems the fact that Tiebout choice is only a weak indicator for the effect of free school choice. Parents have to move to another district in order to vote with their feet. Although there is evidence that parents actually do this (Barrow 2002), fully free choice results in much more competitive pressure as parents can choose other schools in and out of district without moving. 
Unfortunately, the only evidence available is for small-scale free choice or voucher programs as only a few countries in the world provide fully free choice for parents.

Lavy (2010), for example, analyzes the effects of free school choice using an experiment in one of the districts of Tel Aviv (Israel) that allowed parents to choose between public schools both in and out of district. He finds significant positive effects of free school choice on the quality of public schools.

Sandström and Bergström (2005) show that the increased parental choice in Sweden since 1992 as a result of a voucher program supports the hypothesis that school results in public schools improve due to competition with independent schools. However, if competition is measured by the commonly used HerfindahlHirschman concentration index, the effects are sometimes negative and sometimes insignificant. Also, the Swedish voucher program is small: only $7 \%$ of students were enrolled in an independent school in 2004.

Chakrabarti (2008) analyses the effects of a voucher program for private schools in Milwaukee. He finds a larger effect in the second phase of this program, suggesting that the larger availability of places resulted in more positive effects of competition on quality of public schools. He concludes that program characteristics might be important to explain effects of competition on quality. In addition, Hanushek et al. (2007) investigates the quality differences between charter and public schools using data for Texas. They find that quality differences are absent after the start-up phase, which is troublesome for most charter schools. Empirical studies for other US states have tended to find effects ranging from slightly positive to modestly negative on charter school students' reading and math growth (see Bifulco and Ladd (2006) for North Carolina and Sass (2006) for Florida). Nevertheless, studies such as Hoxby and Rockoff (2005) and Hoxby and Murarka (2009) focusing on charters schools in relatively vibrant urban areas, and therefore with abundant choice, have found more positive effects. However, an important limitation of these studies is that they include only schools with oversubscribed lotteries, which are probably the most desirable schools in these areas. Therefore, in a US overview of the vouchers and chartered schools literature Loeb et al. (2011) claim that the empirical evidence of the effectiveness of vouchers in improving student's achievement is decidedly mixed.

Also Rouse and Barrow (2009, p. 22), after summarizing the literature on voucher programs, conclude that these small-scale experiments cannot be used to test Friedman's hypothesis and thus that "many questions remain about the potential long-term impacts on academic outcomes and about both the public and private sector responses to a large, permanent, and well-funded voucher program." ${ }^{1}$ The Netherlands is one of the few countries in the world where such impacts can currently be measured as it has long experience with free choice, the role of both public and private schools is large and funding is the same for all types of schools. The other example might be Chile where 1,000 schools entered the market as a result of a voucher program open for all schools, more or less comparable to the

\footnotetext{
${ }^{1}$ Rouse and Barrow (2009) conclude that "Keeping these limitations in mind, the best research to date finds relatively small achievement gains for students offered education vouchers, most of which are not statistically different from zero."
} 
situation in the Netherlands. Hsieh and Urquiola (2006) found no effects of competition on quality in this case.

In the Netherlands, the model of free parental choice between different types of schools has been present since the historical national school dispute ("schoolstrijd") came to an end in 1917 (Kossmann 1978). ${ }^{2}$ Ever since, parental choice and equal opportunities for public and private schools have even been guaranteed in the Dutch constitution. Private primary and secondary schools are managed by independent non-profit boards, and they abide by practically the same rules as public schools. Many, but not all, private schools have a religious denomination. Private schools are fully financed by the government at exactly the same level as public schools, both based on the number of students. The Dutch system could, in fact, be characterized by a full voucher program with $100 \%$ funding. Parents are free to choose any public or private school in the country. Schools are in principle obliged to accept all students. The only exception the law permits is for religious schools to ask that parents agree with their denomination. In practice, only a few, especially Protestant, schools use this exception. Selection with respect to the a priori quality of students is never allowed. This is an important difference from voucher programs in other countries, where schools can often select the students they want. Free choice is used very often: in $2006,71 \%$ of students are at private schools.

Since the introduction of free parental choice, a large number of private schools entered the market. However, currently, new schools are created only very occasionally. The reason for this is that parents can start up a new school site $^{3}$ as long as they prove that the denomination (or educational method, such as Dalton or Montessori) they present is not yet represented in their surroundings and that there are enough students who want to attend a school with such a denomination. Given the long history, nearly all types of schools already exist. ${ }^{4}$ This means that competition in the Netherlands occurs between existing school sites and not with entrants. This is a very important institutional characteristic which allows us to use the number of school sites as an instrument for competition in the market to test for endogeneity problems. Thus, competition between school sites measured by concentration indices based on market shares (in our case, the HerfindahlHirschman index) might be endogenous with respect to quality as lower quality might lead to changes in market shares if higher-quality schools attract students. The number of school sites, however, is not endogenous in the Netherlands, as low quality in a market is not a possible reason for getting permission to start a new school site. The number of school sites in the Netherlands is therefore exogenous with respect to quality. This is a major difference from US markets, where entry is very often the result of dissatisfaction with existing school quality (Hoxby 2000).

Given the long history of competition between schools in the Netherlands, one would expect effects on quality, if present, to be visible. However, the effect of

\footnotetext{
2 Belgium has a similar system, which appeared in 1958, also after a prolonged battle between religious and secular political parties (Kossmann 1978, p. 273).

3 In the Netherlands, a distinction is made between school boards (or competent authorities for public schools), schools, school sites and education types.

4 The only exception at present is Muslim schools, a few of which have been created recently.
} 
competition on quality has never been systematically analyzed for the Netherlands. In this paper, we fill that gap based on data for secondary schools for the period 2002-2006. We use datasets from the Dutch Ministry of Education and the national monitoring agency for education ("Onderwijsinspectie"). We measure school quality by three achievement variables: the average score in the nationwide final exams, the percentage of students who obtain a diploma and the percentage of students graduating on time. For all three measures, we find evidence of a negative effect of competition on quality, which is quite small. This effect is robust for alternative specifications and sensitivity analyses, including endogeneity-correcting instrumental variable (IV) estimations. We show that the effect is dominated by small and medium-sized schools and by schools that do not have a Protestant or Catholic denomination.

The article is organized as follows. Section 2 discusses the methodology and the available data. The estimation results are presented in Sect. 3 and the robustness of the results is discussed in Sect. 4. Section 5 draws some conclusions.

\section{Methodology and data}

Our main methodology is an econometric test of the effect of competition intensity on the educational outcomes of school sites. In the Netherlands, a distinction is made between school boards (or competent authorities for public schools), schools, school sites and education types. A school board can comprise several schools and a school can have several sites, while each school can supply five education types in one or more sites. Schools are not obliged to provide all education types and they often choose to provide a subset of the five types.

Students finish primary education at an average age of 12 and enroll in one of five levels of secondary education. In increasing order of education level, these are pre-vocational secondary education at three levels $\left(\mathrm{VMBO}_{\mathrm{BA}}, \mathrm{VMBO}_{\mathrm{KA}}\right.$ and $\mathrm{VMBO}_{\mathrm{GT}}$ ), senior general secondary education (HAVO) and pre-university education (VWO). VMBO, lasting 4 years, is intended as preparation for secondary vocational education (MBO) or for HAVO. The BA level is the lowest level, aimed at trade-oriented learning. The highest VMBO level, GT, is theory based and is necessary for students who want to follow the last 2 years of HAVO after finishing VMBO. The intermediate level, KA, combines elements from both BA and GT. HAVO, which lasts 5 years, is intended as preparation for higher vocational education (HBO) and is necessary for students who want to follow the last 2 years of VWO after finishing HAVO. VWO, which lasts 6 years, is intended as preparation for university. In most schools, the final choice between education types is made after the first 2 or 3 years of secondary education, while a first broad streaming (e.g. a combination of HAVO/VWO or VMBO) is based on a nationwide test at the end of primary school and on advice from the primary school teachers.

Our main hypothesis is that school sites compete with each other for students and that this competition affects educational quality. Managers have an incentive to attract more students to increase the size of their institution, as their salaries are often influenced by the size of the site and school. Currently, the maximum 
manager's salary for the smallest schools is 118,000 dollars per year, while managers of the largest schools can earn up to 223,000 dollars per year. ${ }^{5}$ Traditionally, board members were unpaid. Increasingly, however, board members also get a salary, which is often coupled to the size of schools (varying from 3,000 dollars yearly for the smallest schools to 14,000 dollars for the largest). As schools are not allowed to ask for a contribution from parents, and revenues from the government are fixed per student, the way to increase revenues is to increase the number of students. The question is, how does this affect the quality of education? As long as quality is a dominant parameter in the choice set of students (and their parents), a positive effect could be expected. Schools with higher achievements are then able to attract more students. A negative effect, however, could occur if other parameters determine the choice set and schools invest in these parameters instead of in quality (see introduction). Which effect dominates is a matter for empirical analysis.

We estimate a panel model using both cross-section and time-related variation. For each achievement indicator, we estimate the following equation:

$$
Q_{i, t}=\beta C I_{i, t}+\gamma S_{i, t}+\lambda P_{i, t}+c_{s}+d_{t}+\varepsilon_{i, t},
$$

where $Q_{i, t}$ measures achievement of school site $i$ in year $t, C I_{i, t}$ measures competition intensity of school site $i$ in year $t, S_{i, t}$ is a vector of school site characteristics, $P_{i, t}$ is a vector of socio-economic variables for the neighborhood in which the school site is located, $c_{s}$ are time-invariant school (s) fixed effects, $d_{t}$ are time fixed effects (with 2002 as a benchmark) and $\varepsilon_{i}$ is an error term.

Based on administrative data from the national monitoring agency for education ("Onderwijsinspectie"), we distinguish between three school performance measures as the dependent variable: the average exam score based on a national exam in the final year, ${ }^{6}$ the percentage of students graduating and the percentage of students graduating on time. All variables are measured at the site level $i$ for each year $t$ and by education type. Data are available for nearly all sites. The total panel has a maximum of 10,063 observations as we have data for 554 sites, for four (VMBO: 2003-2006) or five (HAVO and VWO: 2002-2006) years and for five education types. In Table 1, summary statistics are shown for the overall sample and for the five education types.

We take as a measure of competition intensity the so-called HerfindahlHirschman index (HHI). The HHI is calculated for each school site and each year based on the share $\left(s_{i, t}\right)$ of the school site's enrollment in total enrollment within a pre-defined geographic area per site (each site has its own geographic area) by education type ${ }^{7}$ :

$$
\mathrm{HHI}_{\mathrm{i}, \mathrm{t}}=\sum_{\mathrm{i}}\left(\mathrm{s}_{\mathrm{i}, \mathrm{t}}\right)^{2}
$$

\footnotetext{
5 We used an exchange rate of 1.25 dollars is 1 euro.

6 This national exam is the same for all Dutch schools, but different for each of the five educational types.

7 For the market shares $\left(s_{i, t}\right)$, we take into account students who are in the last two (VMBO and HAVO) and last three (VWO) years. We disregard student numbers for earlier years because students are not yet streamed finally and precisely to education types.
} 
Table 1 Descriptive statistics for quality variables, years 2002-2006 or 2003-2006 (VMBO)

\begin{tabular}{|c|c|c|c|}
\hline & $\begin{array}{l}\text { Central } \\
\text { exam score }\end{array}$ & $\begin{array}{l}\text { Share graduated } \\
\text { on time }\end{array}$ & $\begin{array}{l}\text { Share } \\
\text { graduated }\end{array}$ \\
\hline \multicolumn{4}{|l|}{ Overall } \\
\hline Mean & 6.42 & 0.76 & 0.94 \\
\hline Minimum & 4.10 & 0.09 & 0.07 \\
\hline Maximum & 7.90 & 1.00 & 1.00 \\
\hline Standard deviation & 0.33 & 0.16 & 0.07 \\
\hline Observations & 10,063 & 9,183 & 10,041 \\
\hline \multicolumn{4}{|l|}{$V W O$} \\
\hline Mean & 6.41 & 0.64 & 0.93 \\
\hline Observations & 2,057 & 1,945 & 2,057 \\
\hline \multicolumn{4}{|l|}{$H A V O$} \\
\hline Mean & 6.24 & 0.60 & 0.90 \\
\hline Observations & 1,973 & 1,893 & 1,973 \\
\hline \multicolumn{4}{|l|}{$V M B O_{G T}$} \\
\hline Mean & 6.35 & 0.85 & 0.95 \\
\hline Observations & 2,718 & 3,022 & 2,698 \\
\hline \multicolumn{4}{|l|}{$V M B O_{K A}$} \\
\hline Mean & 6.45 & 0.86 & 0.96 \\
\hline Observations & 1,671 & 1,177 & 1,670 \\
\hline \multicolumn{4}{|l|}{$V M B O_{B A}$} \\
\hline Mean & 6.73 & 0.89 & 0.95 \\
\hline Observations & 1,644 & 1,146 & 1,643 \\
\hline
\end{tabular}

School sites within a distance of $10 \mathrm{~km}$ are taken into account. ${ }^{8}$ The HHI varies between 0 and 1 . A value of (nearly) 0 indicates that there are many relatively equal-sized school sites in the relevant market. A value of 1 indicates that the school is a monopolist. In the estimations, we use a negative HHI $(-\mathrm{HHI})$ as this is easier to interpret (an increase in competition corresponds to an increase in this measure).

In Tables 2, 3 and 4 descriptive statistics for the HHIs are given. On average, the HHI has a value of 0.35 , indicating that the average site competes with two other sites. An HHI lower than 0.1 reflects a high level of competition and applies to $11 \%$ of all sites. An HHI between 0.1 and 0.2 , indicating moderately concentrated markets, is present in $26 \%$ of all cases. An index between 0.2 and 0.5 applies to $38 \%$ of the school sites and these markets are concentrated. For $26 \%$ of the sites, markets are highly concentrated, with an HHI of 0.5 or more. According to this measure, nearly half of these sites are monopolists $(\mathrm{HHI}=1)$. These figures mean that competition varies a lot by region. Table 3 shows that the HHI changes also significantly between 2002 and 2006 for many locations. Although 1,717 have

\footnotetext{
${ }^{8}$ In the US literature, the HHI is mostly based on a municipality or a district. In the Netherlands, competition takes place within a certain geographic area as the geographic centers of municipalities are much closer to each other. The distances between school sites are calculated using a standard route planner. According to Statistics Netherlands $90 \%$ of students have a school within $5 \mathrm{~km}$. In sensitivity analysis we show that our results are comparable when we choose 7.5 or $5 \mathrm{~km}$ as radius.
} 
Table 2 Share of school sites by level of competition

\begin{tabular}{lccc}
\hline & HHI & Sites & Share of all sites \\
\hline High level of competition & $<0.1$ & 1,071 & 0.11 \\
Low level of competition & $0.1-0.2$ & 2,590 & 0.26 \\
& $0.2-0.5$ & 3,807 & 0.38 \\
Monopoly & $0.5-1.0$ & 1,495 & 0.15 \\
Total & 1.0 & 1,100 & 0.11 \\
\hline
\end{tabular}

Table 3 Number and share of school sites by change in level of competition

\begin{tabular}{|c|c|c|c|c|c|}
\hline \multicolumn{4}{|c|}{ Change in HHI between 2002 and 2006} & \multirow{2}{*}{$\frac{\text { Number of locations }}{23}$} & \multirow{2}{*}{$\begin{array}{c}\text { Share } \\
0.9\end{array}$} \\
\hline Less than & -0.500 & But more than & -0.200 & & \\
\hline & -0.200 & & -0.100 & 56 & 2.2 \\
\hline & -0.100 & & -0.050 & 157 & 6.1 \\
\hline & -0.050 & & -0.025 & 216 & 8.4 \\
\hline & -0.025 & & 0.000 & 1,171 & 45.8 \\
\hline \multirow[t]{6}{*}{ More than } & 0.000 & But less than & 0.025 & 546 & 21.4 \\
\hline & 0.025 & & 0.050 & 218 & 8.5 \\
\hline & 0.050 & & 0.100 & 110 & 4.3 \\
\hline & 0.100 & & 0.200 & 38 & 1.5 \\
\hline & 0.200 & & 0.500 & 22 & 0.9 \\
\hline & & & & 2,557 & 100 \\
\hline
\end{tabular}

stable conditions, with a HHI change less than 0.025 , 406 have a change of more than 0.05. Large changes, more than 0.10, are present for 139 locations. Merger guidelines of the EU and the USA indicate that a delta of 0.025 in the HHI might be an indication for market failure. This is the case for 840 school locations (33\%). As we estimate many of our models with school fixed effects, the changes over time are important for identifying the effect of competition on quality. These figures show that there is considerable change over time in our dataset.

Table 4 shows that the HHI differs with respect to big cities and population density. For other characteristics, differences are more modest.

The effect of competition on the quality of education is estimated using the general HHI measured at the school site level by education type. As an alternative measure for competition intensity, in our sensitivity analysis we use the number of competitors in the market and the HHI measured at the school level.

The first site characteristic we correct for in the estimations is size. ${ }^{9}$ In our model, we include the size of the board (the number of schools per board), the size of the school of which the site is a part (the total number of students) and the size of the

\footnotetext{
9 The effects of size are not influenced by the correlation with competition. Estimations without competition variables or size variables do not lead to other conclusions, while the correlations between competition intensity and the size of schools, sites and boards are only $0.05,-0.06$ and 0.00 respectively.
} 
Table 4 Descriptive statistics for competition variables

\begin{tabular}{|c|c|c|c|c|c|}
\hline & Average & Max. & Min. & $\mathrm{SD}$ & $\mathrm{N}$ \\
\hline $\mathrm{HHI}$ at school site level & 0.35 & 1.00 & 0.04 & 0.28 & 10,063 \\
\hline Largest 21 cities & 0.15 & 0.83 & 0.04 & 0.09 & 3,291 \\
\hline Top $25 \%$ population density ${ }^{a}$ & 0.18 & 1.00 & 0.04 & 0.13 & 2,513 \\
\hline Bottom $25 \%$ pop. density ${ }^{a}$ & 0.56 & 1.00 & 0.04 & 0.31 & 2,502 \\
\hline 1st quintile size school ${ }^{\mathrm{b}}$ & 0.34 & 1.00 & 0.04 & 0.30 & 2,044 \\
\hline 2nd quintile size school ${ }^{\mathrm{b}}$ & 0.31 & 1.00 & 0.04 & 0.24 & 1,929 \\
\hline 3 rd quintile size school $^{\mathrm{b}}$ & 0.37 & 1.00 & 0.04 & 0.27 & 1,966 \\
\hline 4th quintile size school ${ }^{\mathrm{b}}$ & 0.41 & 1.00 & 0.05 & 0.28 & 1,996 \\
\hline 5th quintile size school ${ }^{\mathrm{b}}$ & 0.34 & 1.00 & 0.04 & 0.26 & 2,128 \\
\hline Public & 0.36 & 1.00 & 0.04 & 0.28 & 2,878 \\
\hline Catholic & 0.39 & 1.00 & 0.05 & 0.29 & 1,850 \\
\hline Protestant & 0.35 & 1.00 & 0.05 & 0.27 & 1,662 \\
\hline Neutral & 0.34 & 1.00 & 0.05 & 0.27 & 1,724 \\
\hline Other & 0.32 & 1.00 & 0.04 & 0.26 & 1,949 \\
\hline $\mathrm{HHI}$ at school level & 0.39 & 1.00 & 0.05 & 0.28 & 10,063 \\
\hline Number of competitors & 5.46 & 35 & 0 & 5.55 & 10,063 \\
\hline
\end{tabular}

For definitions of variables, see Appendix

a Per site

${ }^{\mathrm{b}}$ With respect to number of students

site at the education type level (the number of students by education type). ${ }^{10}$ The second site characteristic is related to the type of education provided. We include dummies with value 1 if one of the five types is provided, with VWO as the benchmark. See Table 5 for descriptive statistics.

No socio-economic data on characteristics of the student population are available at the site level. Therefore we use data that are available for the zip code of the site. ${ }^{11} \mathrm{We}$ include the following socio-economic characteristics: the number of non-western foreigners per 100 inhabitants (foreigners), the average income per inhabitant in thousands of euros (income) and population density. The only demographic information available at the site level for the whole period is gender (the share of girls). The data for the socio-economic characteristics for each zip code are obtained from Statistics Netherlands. See Table 5 for descriptive statistics. Note that we also include school and year fixed effects to correct for unobserved heterogeneity. We use fixed effects at the school level as the time dimension is limited. ${ }^{12}$

\footnotetext{
${ }^{10}$ We tested for multicollinearity between these variables and did not find any indication of this. We excluded the size of the site summed over education types as this variable has a very high correlation with size by education type.

11 Zip codes in the Netherlands are alphanumeric, consisting of four digits (followed by two letters). These four-digit zip codes are geographic areas of towns or municipalities and the Netherlands has more than 4,000 such areas. The average size of these areas is $10.3 \mathrm{~km}^{2}$.

12 Fixed effects for sites would result in only 9 observations per group for identification of the competition effect. With school fixed effects we have 18 observations per group, which indicates that these effects are already very detailed (554 groups for 10,063 observations).
} 
Table 5 Descriptive statistics for other variables

\begin{tabular}{llllll}
\hline & Average & Max. & Min. & SD & N \\
\hline Size site (students) & 219 & 1,553 & 10 & 164 & 10,063 \\
Size school (students) & 2,242 & 10,492 & 27 & 1,414 & 10,063 \\
Size board (schools) & 13 & 74 & 1 & 19 & 10,063 \\
Education level (share) & & & & \\
VWO & 0.20 & 1.00 & 0.00 & 0.40 & 10,063 \\
HAVO & 0.20 & 1.00 & 0.00 & 0.40 & 10,063 \\
VMBOGT & 0.27 & 1.00 & 0.00 & 0.44 & 10,063 \\
VMBO & 0.17 & 1.00 & 0.00 & 0.37 & 10,063 \\
VMBO & 0.16 & 1.00 & 0.00 & 0.37 & 10,063 \\
Girls (share) & 0.49 & 1.00 & 0.00 & 0.09 & 10,063 \\
Foreigners (share) & 0.10 & 0.80 & 0.00 & 0.11 & 10,063 \\
Income ('000 euros) & 13.0 & 29.0 & 8.0 & 2.4 & 10,063 \\
Population density (inhabitants/km ${ }^{2}$ ) & 4,027 & 26,046 & 46 & 3,033 & 10,063 \\
Year 2002 & 0.09 & 1.00 & 0.00 & 0.28 & 10,063 \\
Year 2003 & 0.21 & 1.00 & 0.00 & 0.41 & 10,063 \\
Year 2004 & 0.23 & 1.00 & 0.00 & 0.42 & 10,063 \\
Year 2005 & 0.24 & 1.00 & 0.00 & 0.42 & 10,063 \\
Year 2006 & 0.23 & 1.00 & 0.00 & 0.42 & 10,063 \\
\hline For (efinitions & & & & &
\end{tabular}

For definitions of variables, see Appendix

\section{Results}

Table 6 presents the estimation results. For all three achievement indicators, a significant negative relationship is found between quality and competition. These results suggest that more competition decreases the quality of education. However, the effects are not large. If competition increases from monopoly $(\mathrm{HHI}=1)$ to full competition $(\mathrm{HHI}=0)$, the average central exam score decreases by 0.05 . With the same change, the percentage of students graduating decreases by $1.1 \%$-points and the percentage of students graduating on time decreases by $1.7 \%$-points. A smaller change in competition intensity is more probable, especially because in the Netherlands competition takes place between existing school sites and not with entrants. Assume, for example, that a dominant firm with $60 \%$ market share loses students to four other schools with $10 \%$ market share each, with the ex-post result that all schools have equal market shares (resulting in an HHI decrease from 0.40 to 0.20). In this case, the average central exam score decreases by 0.01 , while the percentages of graduated and on-time graduated students decrease by $0.2 \%$-point and $0.3 \%$-point respectively. This means that, although we find a significant relationship between competition and quality, the effects are fairly small.

Scale effects are found for the central exam score if site size or school size increases. These effects are small. If the site size is increased by 1,000 students, the central exam score rises by 0.11 . This effect is -0.06 if the school size increases by 
Table 6 Estimation results basic model

\begin{tabular}{|c|c|c|c|c|c|c|}
\hline & \multicolumn{2}{|c|}{ Central exam score } & \multicolumn{2}{|c|}{ Share graduated on time } & \multicolumn{2}{|c|}{ Share graduated } \\
\hline & Coef. & $\mathrm{SE}$ & Coef. & $\mathrm{SE}$ & Coef. & SE \\
\hline$-\mathrm{HHI}$ & -0.050 & $(0.019)^{* * *}$ & -0.017 & $(0.007)^{* *}$ & -0.011 & $(0.004)^{* *}$ \\
\hline Size site ('000s) & 0.112 & $(0.027)^{* * *}$ & 0.010 & $(0.011)$ & -0.007 & $(0.006)$ \\
\hline Size school ('000s) & -0.064 & $(0.018)^{* * *}$ & -0.014 & $(0.007)^{* *}$ & -0.016 & $(0.004) * * *$ \\
\hline Size board (schools) & 0.001 & $(0.001)$ & 0.000 & $(0.000)$ & 0.000 & $(0.000)$ \\
\hline HAVO & -0.143 & $(0.008)^{* * *}$ & -0.033 & $(0.003)^{* * *}$ & -0.030 & $(0.002) * * *$ \\
\hline $\mathrm{VMBO}_{\mathrm{GT}}$ & 0.003 & $(0.009)$ & 0.216 & $(0.003)^{* * *}$ & 0.015 & $(0.002)^{* * *}$ \\
\hline $\mathrm{VMBO}_{\mathrm{KA}}$ & 0.114 & $(0.010)^{* * *}$ & 0.199 & $(0.004)^{* * *}$ & 0.026 & $(0.002)^{* * *}$ \\
\hline $\mathrm{VMBO}_{\mathrm{BA}}$ & 0.395 & $(0.010)^{* * *}$ & 0.234 & $(0.004)^{* * *}$ & 0.024 & $(0.002) * * *$ \\
\hline Girls & -0.002 & $(0.039)$ & 0.027 & $(0.017)$ & 0.037 & $(0.009)^{* * *}$ \\
\hline Foreigners & -0.238 & $(0.054) * * *$ & 0.003 & $(0.021)$ & -0.007 & $(0.012)$ \\
\hline Income ('000s) & 2.221 & $(2.315)$ & -1.829 & $(0.913)^{* *}$ & -0.565 & $(0.537)$ \\
\hline Population density ('000s) & 0.001 & $(0.002)$ & -0.001 & $(0.001)$ & -0.001 & $(0.000)^{* * *}$ \\
\hline Year 2003 & 0.012 & $(0.010)$ & 0.025 & $(0.003)^{* * *}$ & 0.004 & $(0.002)^{*}$ \\
\hline Year 2004 & -0.013 & $(0.010)$ & 0.046 & $(0.003)^{* * *}$ & 0.007 & $(0.002) * * *$ \\
\hline Year 2005 & -0.055 & $(0.011)^{* * *}$ & 0.065 & $(0.003)^{* * *}$ & 0.006 & $(0.002)^{* *}$ \\
\hline Year 2006 & -0.037 & $(0.011)^{* * *}$ & 0.075 & $(0.003)^{* * *}$ & 0.005 & $(0.002)^{*}$ \\
\hline Constant & 6.469 & $(0.061)^{* * *}$ & 0.633 & $(0.024)^{* * *}$ & 0.952 & $(0.014)^{* * *}$ \\
\hline $\mathrm{R}^{2}$ (within) & 0.30 & & 0.63 & & 0.11 & \\
\hline Observations & 10,063 & & 9,192 & & 10,057 & \\
\hline
\end{tabular}

Standard errors in parentheses. $* / * * / * * *$ Significance at $10 / 5 / 1 \%$. Models are estimated with school fixed effects, which are available upon request. For definitions of variables, see Appendix

the same number. For the share undelayed and the share graduated, only the school size has an influence, which is small and negative.

For time effects, the exam score declines over time but the percentage of undelayed graduated students increases over time. Thus, there are fewer students with delay, but the price appears to be a lower exam score.

Turning to the socio-economic characteristics, we find significant negative effects on the central exam score if a school is located in a neighborhood with a high percentage of non-western foreigners. The share of graduated students is lower when the population density increases. It should be noted, however, that we include detailed fixed effects (by school), which might interact with these variables. Indeed, models without fixed effects show highly significant coefficients for foreigners, income and population density for all three quality measures. ${ }^{13} \mathrm{We}$ find no indication that the gender effect is important for the central exam score or for the share of undelayed students, but the share of graduated students is higher with a larger share of girls.

\footnotetext{
$\overline{13}$ Details are available on request.
} 


\section{The robustness analysis}

It could be argued that the effect of competition is not homogeneous. First, a difference could be present between urban and rural areas. As competition is generally higher in urban areas, it is possible that our main results are in fact driven by differences between urban and rural areas. To test this, we include an additional effect for the 21 Largest cities and for the sites located in areas with a relatively low (bottom $25 \%$ ) or high (top $25 \%$ ) population density. The HHI is indeed much lower in the 21 big cities, with an average value of 0.15 (Table 4). This is comparable to the level of 0.18 for the sites in the areas with the highest population densities. Sites in the bottom $25 \%$ of areas have an HHI of 0.56. Still, we do not find support for the heterogeneity hypothesis (Table 7, models 1 and 2). ${ }^{14}$ None of the coefficients is significant at the usual levels for a separate competition intensity effect for big cities or for areas with a low or high population density.

A second type of possible heterogeneity is related to the size of schools. It could be argued that smaller schools have a higher need to attract additional students and thus compete more fiercely. One reason for this is that small schools profit more from scale economies in costs and reputational effects if their size increases. A second reason is that small schools can lose their permit if their size drops below a certain level. Finally, the wage level of managers is often coupled to the size of schools, providing incentives to scale up, especially for managers of smaller schools. To test this, first we include an additional variable measuring the multiplicative effect of HHI and school size and, second, we replace the HHI by HHIs in size quintiles. ${ }^{15}$ We indeed find some evidence for a relation between the effect of competition intensity and size (Table 7, models 3 and 4). The coefficient for HHI, at -0.16 , is now three times as high as in the basic model for the effect on central exam score, but decreases if schools become larger. At the average size (1,713 students), the effect is -0.096 . The effect becomes zero for schools with about 4,200 students. For the shares of students graduating and students graduating on time, however, the multiplicative effect is insignificant. In the specification with quintiles, it is clear that the effect is dominated by the first two quintiles, although some smaller effects are found for the 4th or 5th quintile. This means that the negative effect of competition on quality is dominated by small and medium-sized schools.

A third type of possible heterogeneity is related to the denomination of schools. Students are in principle free to choose any school in the Netherlands. Certain private schools, however, have a special relationship with a subgroup of inhabitants. Catholic schools, for instance, will be more attractive for students with a Catholic background. This might influence the real competition intensity schools feel. To test this, we include additional parameters for the HHI variable by type of private school. We distinguish between Catholic (18\% of the total), Protestant $(17 \%)$,

\footnotetext{
14 Full estimation results for the models presented in Tables 7 and 8 are available on request.

15 Schools are divided into five equal-sized groups with respect to school size. These groups have cut-off points at respectively 1,201,1,713,2,266 and 2,983 students. We also include dummies for size classes to prevent possible non-linear scale effects being included in coefficients for multiplicative effects.
} 


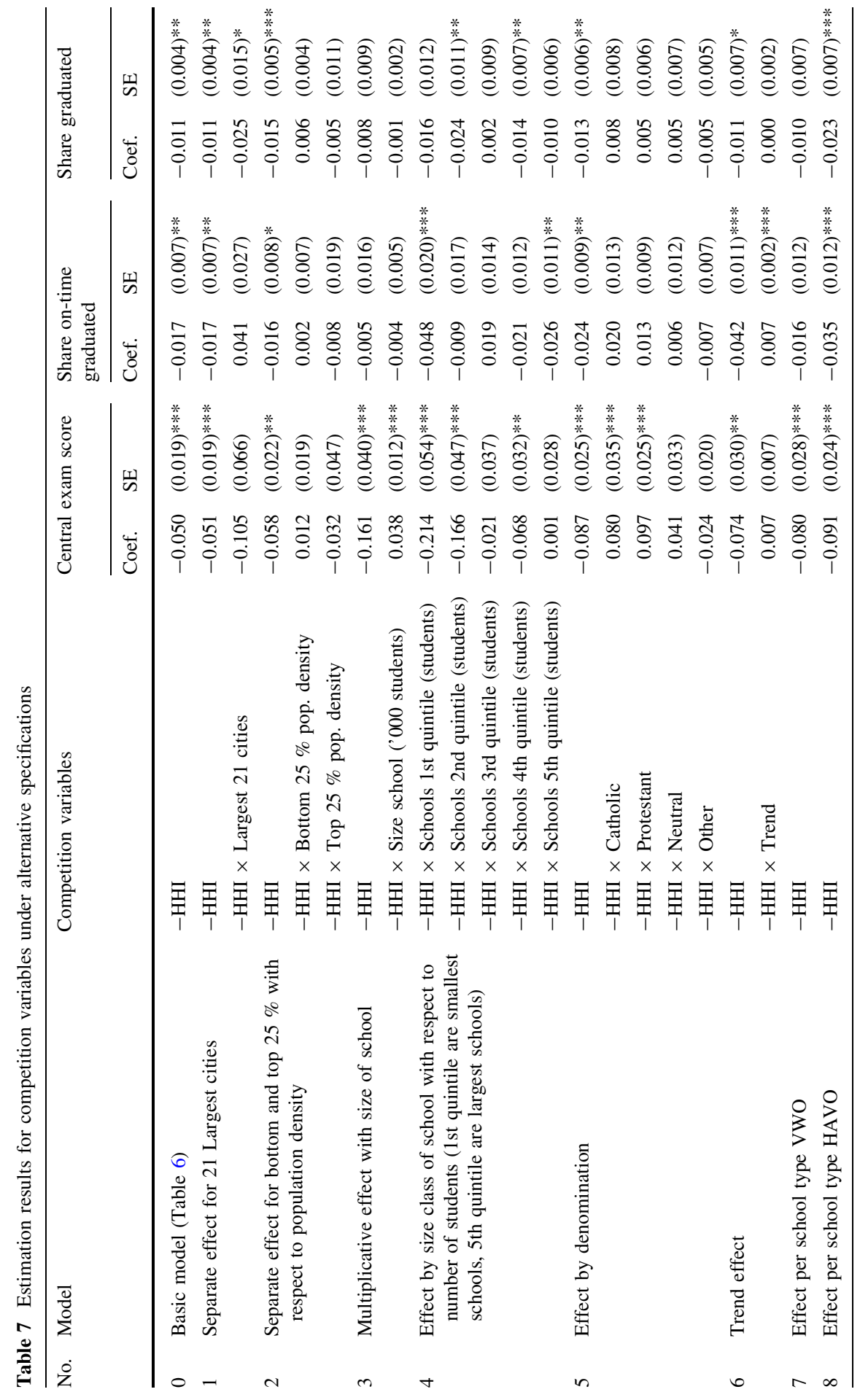




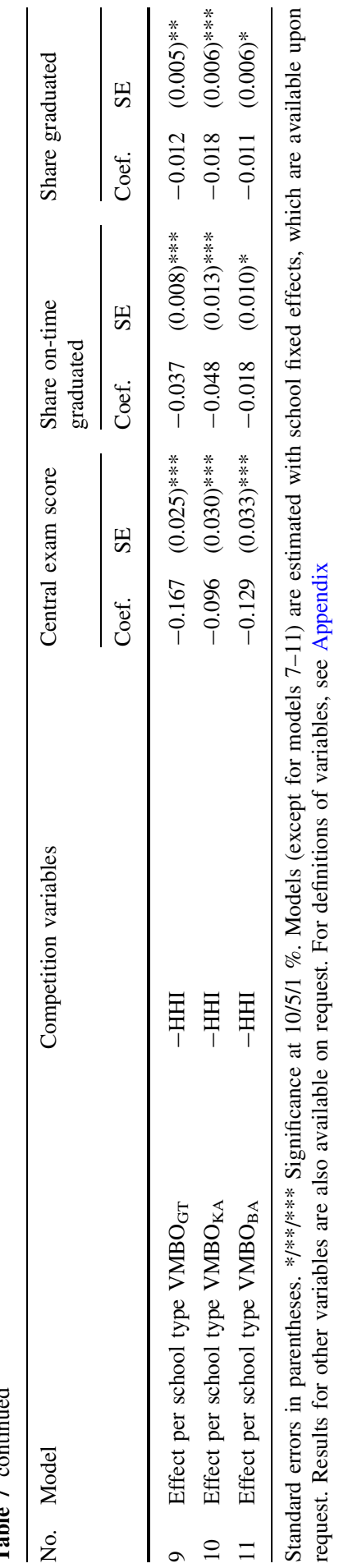


neutral $(17 \%)$ and other $(19 \%)$ private schools. This last group is the combination of several small denominations such as Orthodox Protestant, Anthroposophist and Islamic. We find evidence of a denominational effect for the central exam score (Table 7, model 5). Effects are roughly zero for Protestant and Catholic schools, while the effects for other private and public schools are now higher $(-0.09)$ than in the basic model.

A fourth type of possible heterogeneity is related to time. Newspapers and popular journals publish increasingly reliable information on the quality of schools, and the quality variables for all schools have been available on the internet since 2004. It might take time before a significant number of students and their parents make use of this information, and students and their parents might need time to get used to using this information properly. It could therefore be argued that the competition effect on quality changes over time as information on quality becomes better available for students and their parents. We test this by including an additional variable multiplying the $\mathrm{HHI}$ by a time trend. Only the estimation using the share of on-time graduated students results in a significant coefficient (Table 7, model 6). Here we find evidence that the effect was larger at the beginning of our time frame. After 6 years, which lies outside our sample, the effect becomes zero.

A final type of heterogeneity is related to school type. It could be possible that quality plays a different role per school type. Model 7 to 11 tests whether this is the case. In general significant and negative effects are found. Only for VWO and $\mathrm{VMBO}_{\mathrm{BA}}$ for two quality variables no significant effects are found.

It could be possible, of course, that combinations of heterogeneity are important. Table 8, therefore, presents results for combinations of school size, population density, school type and denomination. ${ }^{16}$ It shows that the results are rather robust.

If school size and population density are combined (model 12), the main results for models 2 and 4 are replicated (although results are no longer significant for the 4 th and 5th quintile). For the central exam score we find only an effect for schools in the 2 nd quintile in low population density areas. Although this effect is positive, it is only significant at $90 \%$ and the net effect is still negative as the single effect of the 2nd quintile is larger. For the share on-time graduated we find many significant effects. They are all negative.

If school size, population density and school type are combined (models 13), several significant effects are found. Although some of these effects are positive, the net effects are always not significant or negative as the coefficients for the single effects are compensating the positive effects. This shows that for some combinations the effect of competition on quality is much smaller or even insignificant.

Model 14 combines the effect of denomination and population density. Positive effects are found for private schools compared with public schools, but only in high population density areas. However, again the net effect is negative or insignificant as the single effects are dominating or compensating.

To analyze the robustness of the estimations further, we test for endogeneity. One could argue that there is also an effect of quality on competition. This would be so if low-quality performance of schools invokes an increase in competition because it

$\overline{16}$ We thank an anonymous referee for this suggestion. 


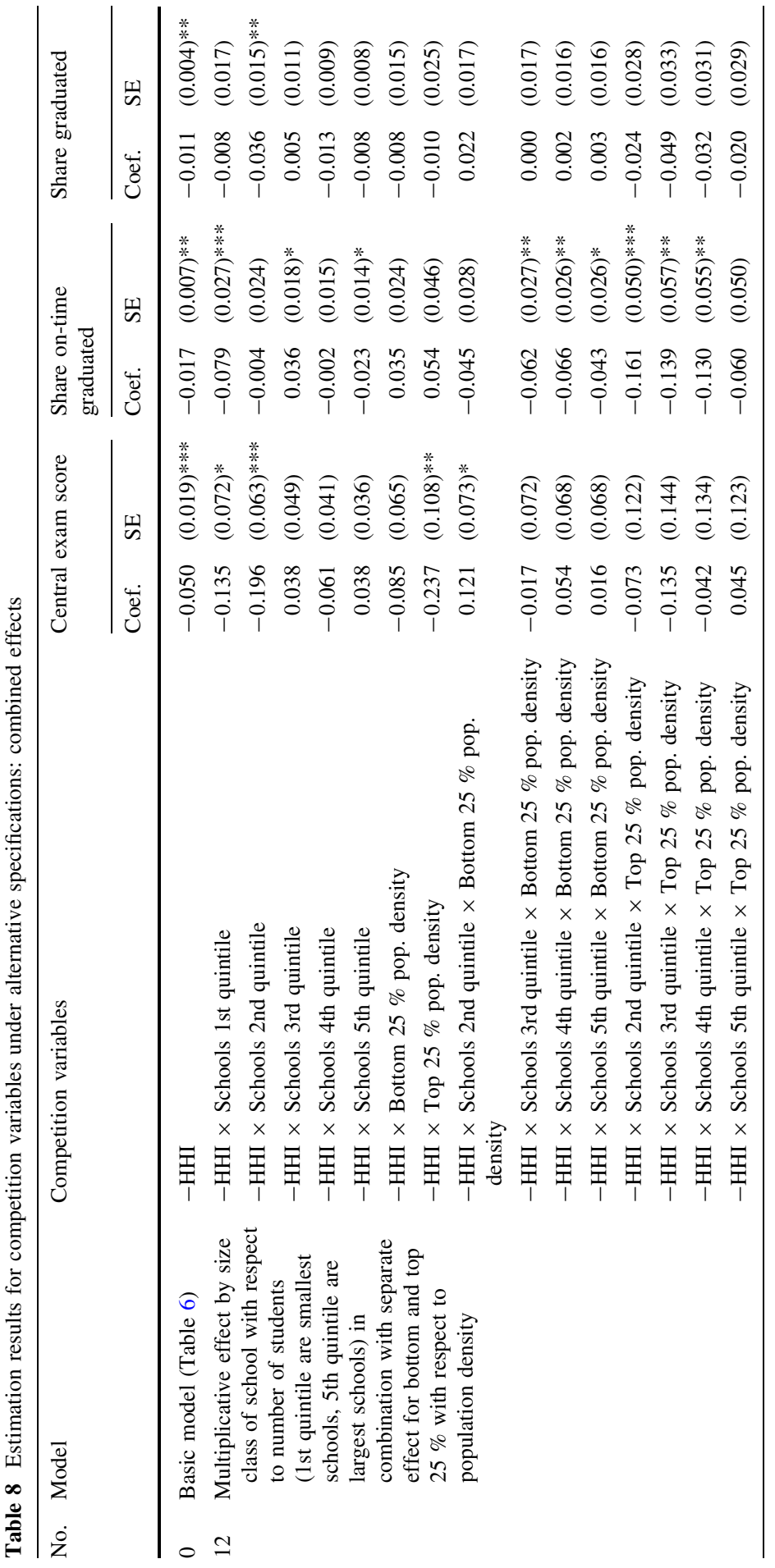

\section{型 Springer}




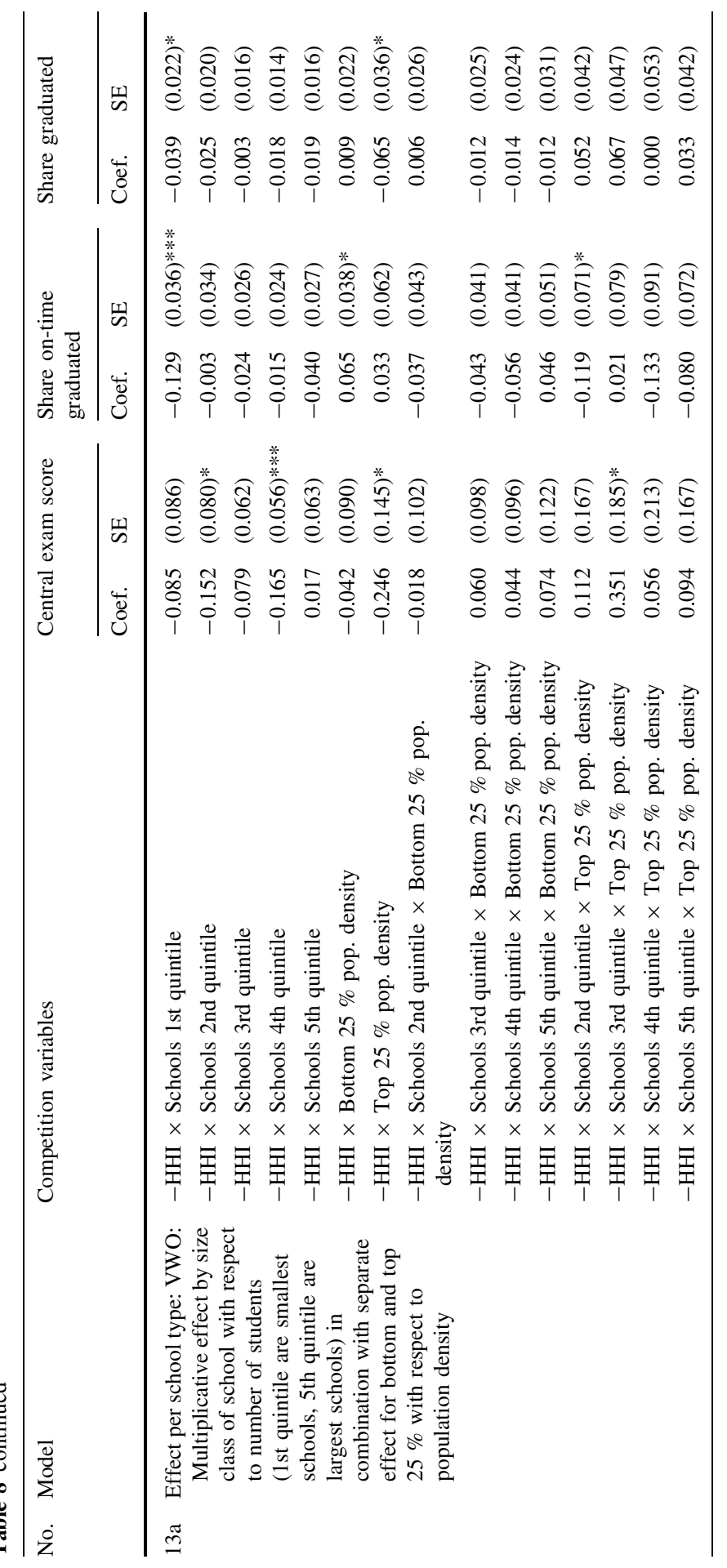




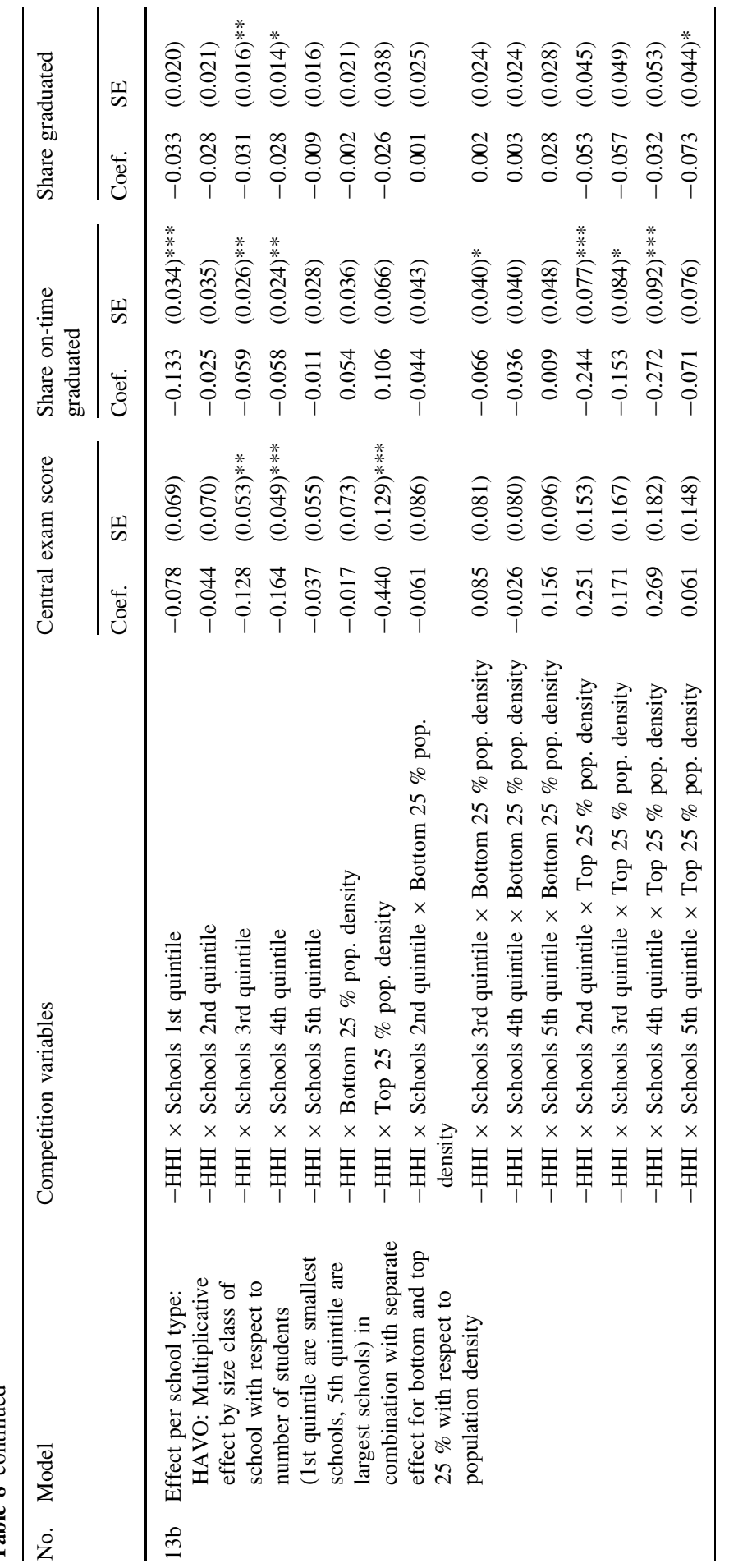




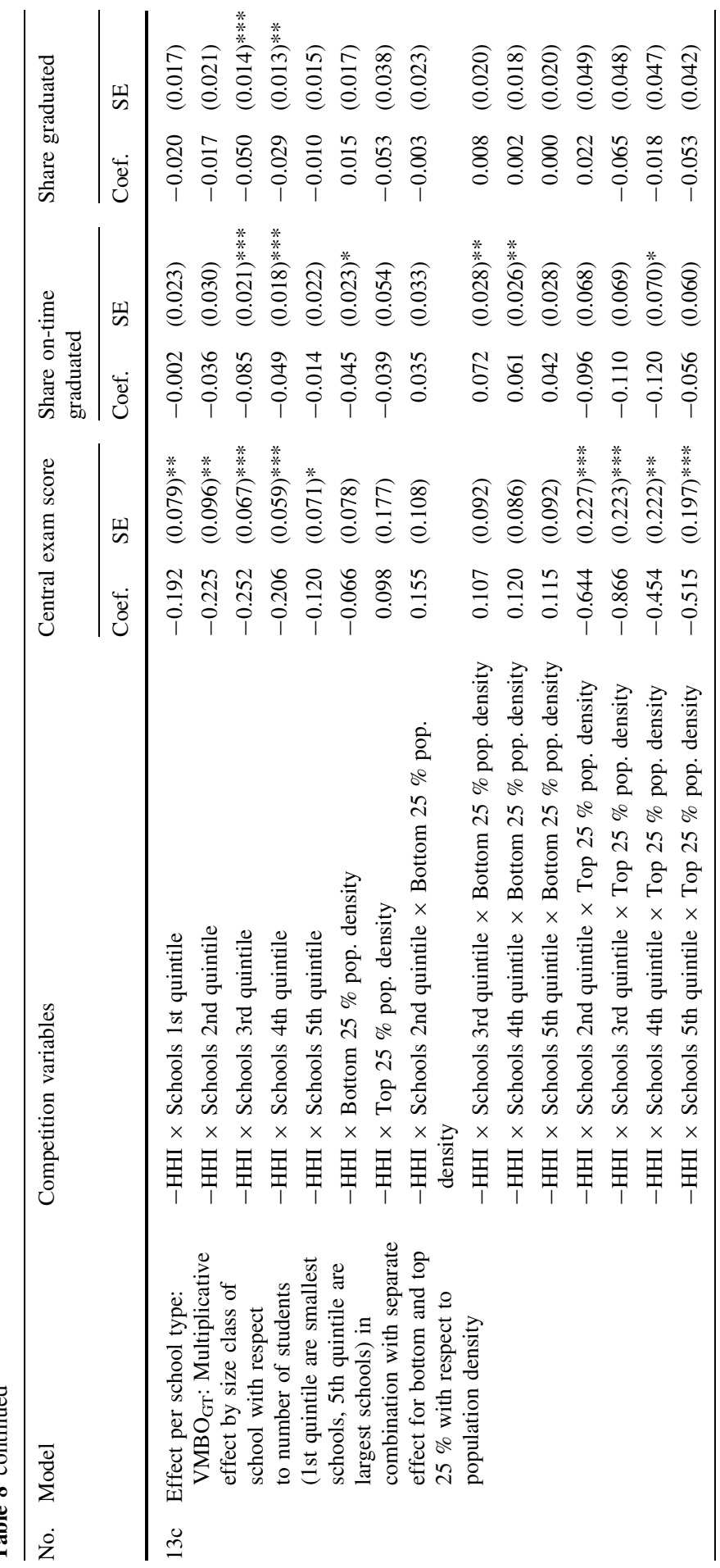




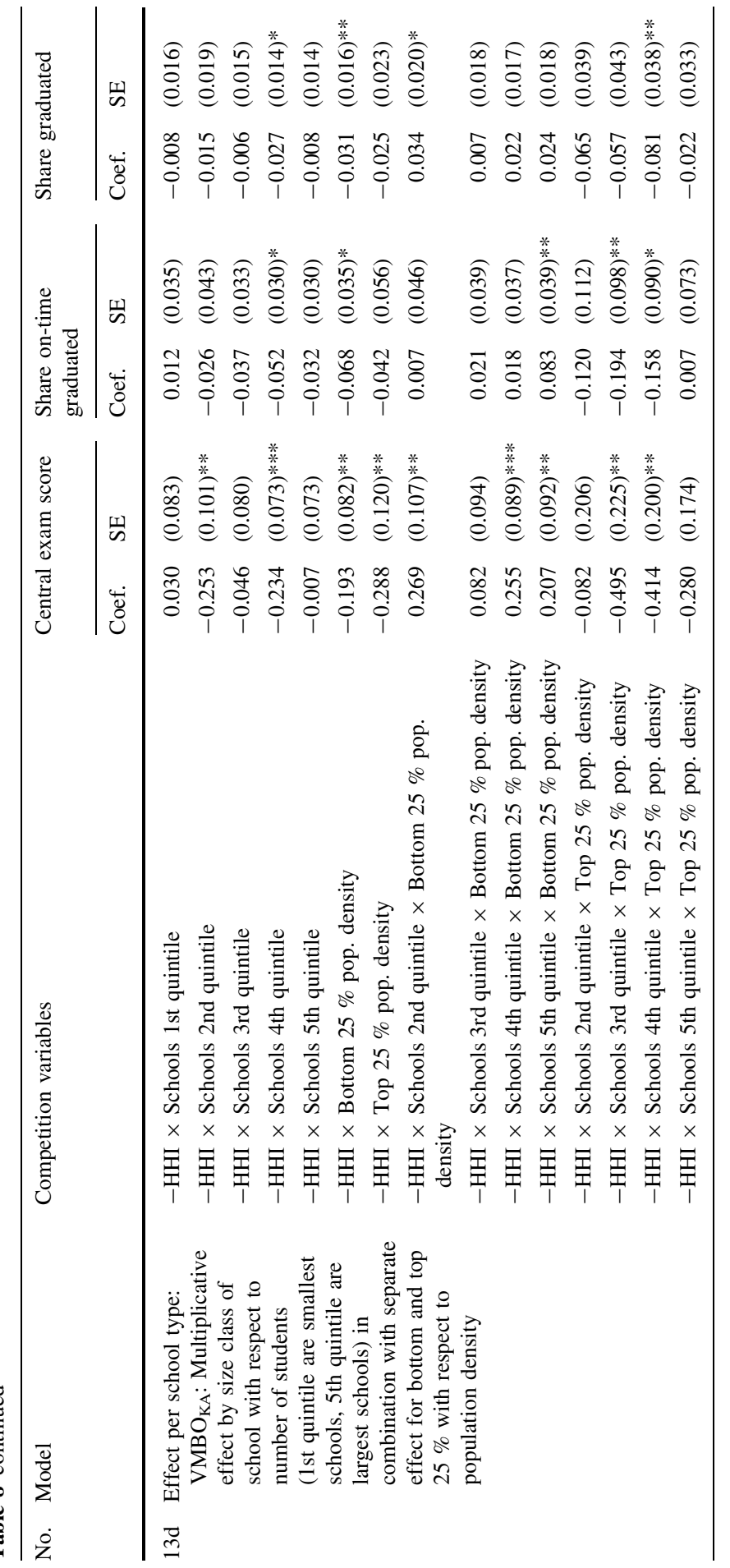




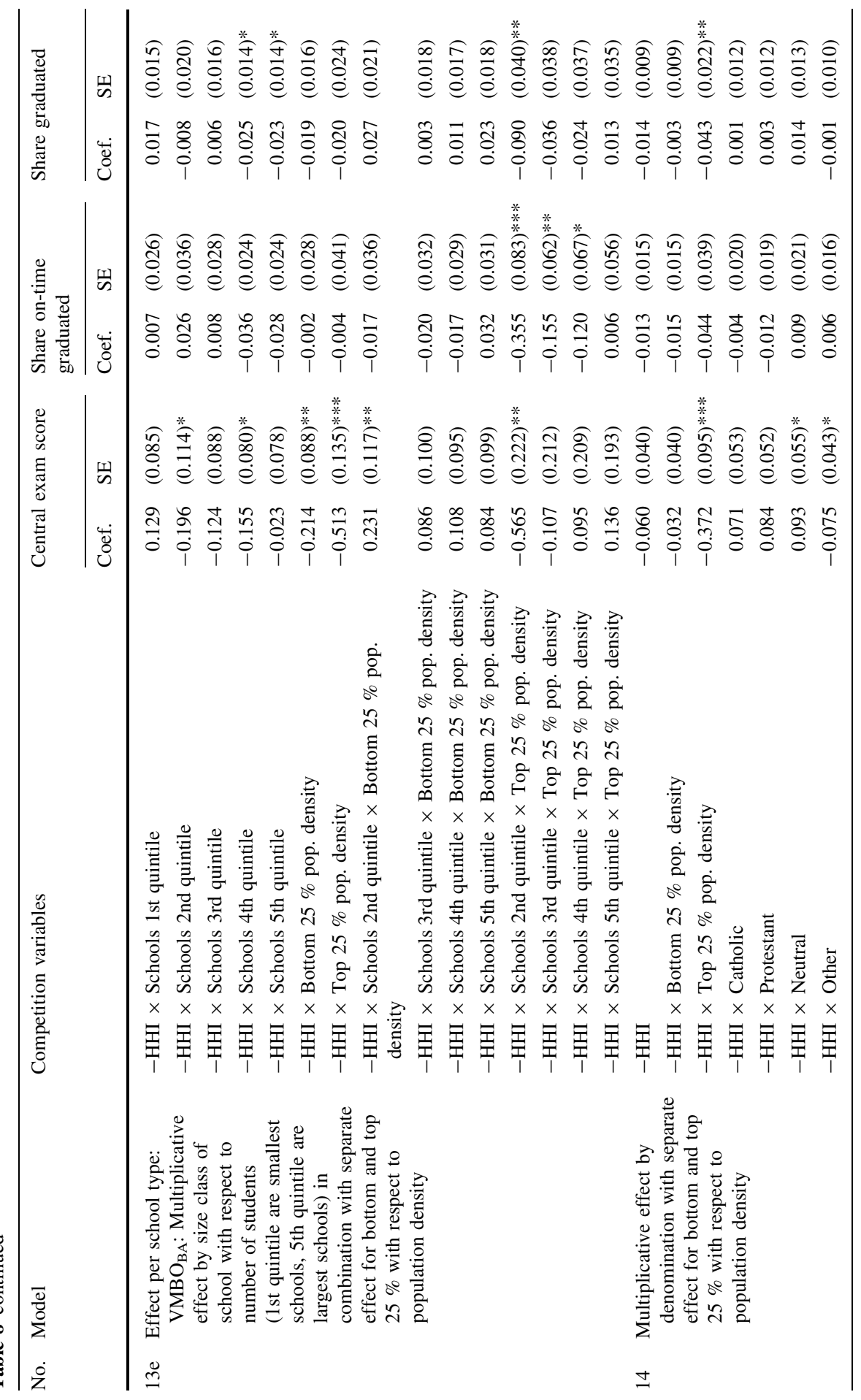




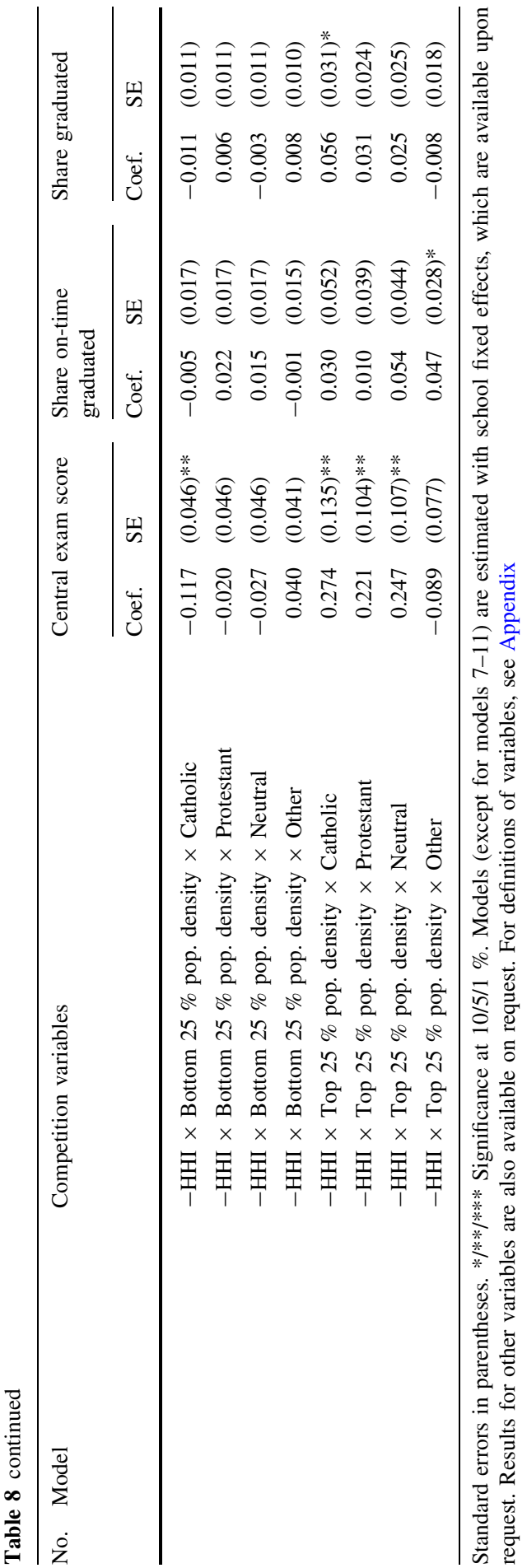


provides opportunities for other schools to compete on quality. If this is the case, our estimations might be biased. An alternative for the basic model is IV estimation where the HHI is replaced by an instrument [as applied, for instance, by Sandström and Bergström (2005) and Hoxby $(2000,2007)]$. We use the number of competitors in the market as an instrument. ${ }^{17}$ While market shares, and thus the HHI, might be endogenous to quality, in the Netherlands the number of competitors cannot be endogenous to quality. As the introduction shows, creation of school sites is (nearly) non-existent. More importantly, low quality in a certain market can never be a reason to start a new school site. If this were the reason given by certain parties for starting a new school site, permission would not be granted. Only when denominations (or specific educational methods) are not present in the relevant market is such permission granted. The number of school sites is, therefore, exogenous by law. This is a major difference from US markets, where entry is very often the result of dissatisfaction with existing school quality (Hoxby 2000). Table 9 presents the results for the IV estimator based on two-stage least squares (2SLS) estimation (model 15). We find that the reported negative effect of competition on quality is robust to endogeneity as none of the coefficients for the competition variables is significantly different from the basic estimates. Next, we test for endogeneity by using lagged values of HHI (model 16, 17 and 18). If there is an effect of quality on competition levels, this should not be the case with lagged values. In most cases we find again significant and negative results. If we find no significant negative effects, they are never positive.

Next, we test alternative assumptions for the competition variable. First, competition is measured by the number of school sites in the market. Second, competition is measured at the level of the school instead of the school site to reflect the case of competition taking place at school level instead of site level. Third, we decrease the radius for schools when calculating HHI to 7.5 and $5 \mathrm{~km}$. In nearly all cases, we again find a negative effect of competition on quality (Table 9, models 19, 20, 21 and 22). Fourth, we investigate whether there is a non-linear effect between competition and quality by including a quadratic term for the HHI variable, as in Aghion et al. (2005). Although the coefficients for quadratic effects are significant for the central exam score and the share of on-time graduated students, the negative effect is still present in nearly all cases (Table 9, model 23). Only when the HHI decreases over the range from 1.0 (monopoly) to 0.8 is a very small increase in quality (0.01) observed. Estimations with a separate effect for this HHI range, however, show that this is the result of overshooting given the quadratic specification (Table 9, model 24). Although all three coefficients for the separate effects are positive, they are never significant. This holds also when we have a separate dummy for monopolies (Table 9, model 25).

\footnotetext{
17 To be precise, we use $(1 /($ number of competitors +1$))$ as an instrument to obtain a measure between 0 and 1 that is comparable to the HHI variable, which makes comparison of coefficients with our basic estimates easier. Alternative specifications with, for example, (1/(number of competitors)) or (1/(number of competitors +3$)$ ) all result in negative and significant coefficients.
} 


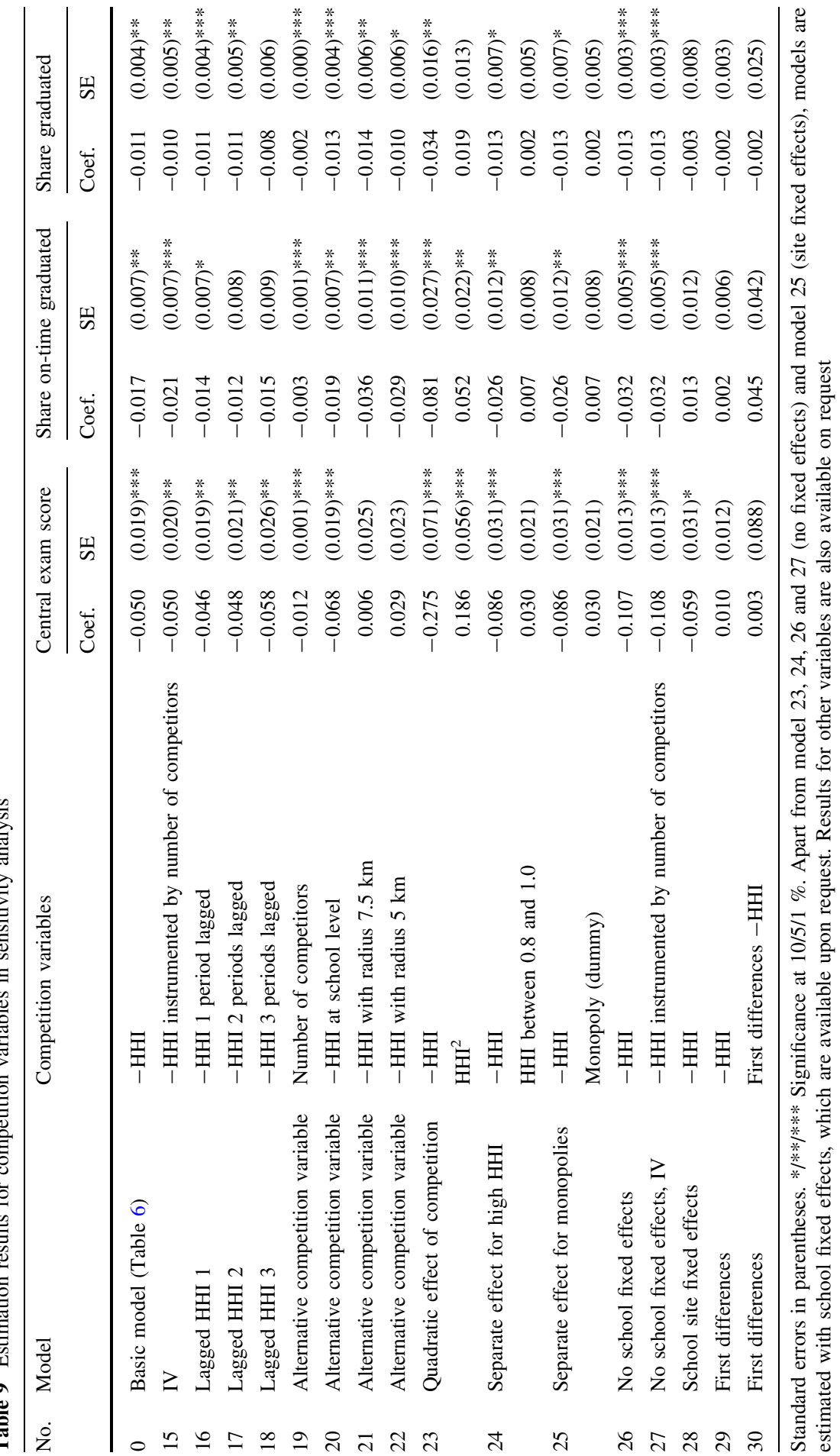


One can argue that fixed effects models are not optimal in our case as they make it impossible to fully use the heterogeneity between schools. We estimate models without fixed effects for schools and find that coefficients are significant and negative, but much higher for the central exam score and the share on-time graduated (Table 9, model 26). This means that panel estimations are important as fixed effects can correct for unobserved heterogeneity. But, more important, with or without fixed effects, we find significant and negative results. This is also the case when the model without fixed effects is combined with the before mentioned IVestimator (model 27).

Next, we test for the opposite case, if school fixed effects are not detailed enough. Although we think that this is not the case, as we have already 554 fixed effects, we estimate the model with school site fixed effects (Table 9, model 28) and again find no positive effects. Still, the effects are even more modest now and we find now only for the central exam score a negative and significant effect. Note, however, that we now have very few observations per unit (9) as the time frame is rather small and we probably ask too much from our data as the only identification comes now from the time-dimension. Finally, we test the effect of competition using first differences for the endogenous variables without and with first differences for the HHI variable (Table 9, model 29 and 30). We find only insignificant results.

Summarizing, the negative relationship we regularly find between competition and quality for Dutch secondary schools is fairly robust, but the effect is larger for small and medium-sized schools and for schools that are not Catholic or Protestant. In some cases we find insignificant effects, but found effects are never positive.

\section{Conclusions}

An interesting debate on the effect of competition between schools is taking place in the literature. Based on Friedman's hypothesis it is claimed that competition enhances quality. However, if quality plays a minor role in the choices made by students and their parents, the opposite effect could be possible. The empirical tests of the hypothesis that competition improves quality are based on countries where only a low level of competition is present. Tiebout choice, small-scale voucher programs and experiments do not necessarily shed light on the long-term effects of fully free parental choice. In the Netherlands, free parental choice has been the leading principle since the beginning of the last century and could be characterized as a full voucher program with $100 \%$ funding. Nevertheless, empirical analysis of the effect of this free parental choice on educational achievements has not taken place; this paper fills that gap for secondary education based on 2002-2006 school site data, We find regularly a negative relation between competition and the quality of educational outcomes, but that the effect is small. This effect is robust for alternative specifications and sensitivity analyses, including endogeneity-correcting IV estimations. We have shown that the effect is dominated by small and mediumsized schools and by schools that do not have a Protestant or Catholic denomination. In some cases we find insignificant results. But we have never found a positive and significant effect. 
These findings especially contradict Hoxby (2007), Chakrabarti (2008) and Lavy (2010). Given the fact that only our analysis is based on fully free choice, which has been available on a large scale and for a long time, it could be argued that our results give a better approximation of the long-term effects. However, the results are consistent if quality of educational outcomes plays a much larger role in school choice in Israel and the US than in the Netherlands. Interestingly, this result is in line with Chakrabarti (2008), who found that effects depend on the characteristics of the voucher program. This would suggest that there is no general answer on the question what the effect of competition on educational quality is. Our results are in main lines consistent with Hsieh and Urquiola (2006) as they found no significant effects of competition on quality after a large scale voucher program in Chile and with Hanushek et al. (2007) who found no differences in quality between public and charter schools in Texas.

There are several avenues to explore in future research. First, broader measures of quality should be used. It could be that competition has a positive effect on quality aspects other than educational outcomes. Lavy (2010) provides first evidence for such effects, finding that behavioral outcomes improved after the introduction of free choice in Tel Aviv. Second, and related to the first point, it could be the case that the quality measures we investigate are not decisive for parents. It is possible that other aspects, like the curriculum, sport programs and the school building are more important for parents to choose between schools. If schools know this, investments in these aspects will diminish the available money for the quality aspects measured in this paper. This could explain the found negative effect. It would be worthwhile to test this in a new paper directly. Third, it could be possible that some parents, particularly those who are worse-off, simply choose the nearest school. Although this need not influence the results per definition, as the marginal chooser might be more important, it is worthwhile to test whether differences in choice behavior influences the results. Fourth, it would be interesting to investigate the effects of competition on quality for primary schools as well, where distance is a more important feature of school choice. Fifth, if data become available for more years, it would be possible to investigate whether the found relationship still holds over a longer time span. The effect of public discussion and increasing transparency using the internet might diminish the negative effects after a few years if the role of quality in choosing schools increases. Finally, it is worthwhile to test whether effects are consistent between countries as education sectors and people differ. It might be the case that competition plays different roles in different countries.

Open Access This article is distributed under the terms of the Creative Commons Attribution License which permits any use, distribution, and reproduction in any medium, provided the original author(s) and the source are credited. 


\section{Appendix: List of variables}

\begin{tabular}{|c|c|}
\hline $\begin{array}{l}\text { Competition } \\
(-\mathrm{HHI})\end{array}$ & $\begin{array}{l}\text { Minus Herfindahl-Hirschman index at site level (sum of market shares of school } \\
\text { sites within radius of } 10 \mathrm{~km} \text { ) }\end{array}$ \\
\hline $\begin{array}{l}\text { Competition } \\
\text { (\# competitors) }\end{array}$ & Number of competitors at site level within radius of $10 \mathrm{~km}$ \\
\hline $\begin{array}{l}\text { Competition } \\
\text { (-HHI school } \\
\text { level) }\end{array}$ & $\begin{array}{l}\text { Minus Herfindahl-Hirschman index at school level (sum of market shares of schools } \\
\text { within radius of } 10 \mathrm{~km} \text { ) }\end{array}$ \\
\hline Monopoly & Dummy with value 1 if $\mathrm{HHI}=1$ (and zero otherwise) \\
\hline Largest 21 cities & $\begin{array}{l}\text { Dummy with value } 1 \text { if site is situated in one of the } 21 \text { largest cities (these cities } \\
\text { have more than } 118,000 \text { inhabitants) and } 0 \text { otherwise }\end{array}$ \\
\hline $\begin{array}{l}\text { Population } \\
\text { density }\end{array}$ & Number of inhabitants per $\mathrm{km}^{2}$ \\
\hline $\begin{array}{l}\text { Bottom } 25 \% \\
\text { pop. density }\end{array}$ & $\begin{array}{l}\text { Dummy with value } 1 \text { if site is situated in a zip-code area with a low population } \\
\text { density ( } 75 \% \text { of areas have higher density) and } 0 \text { otherwise }\end{array}$ \\
\hline $\begin{array}{l}\text { Top } 25 \% \text { pop. } \\
\text { density }\end{array}$ & $\begin{array}{l}\text { Dummy with value } 1 \text { if site is situated in a zip-code area with a high population } \\
\text { density ( } 75 \% \text { of areas have lower density) and } 0 \text { otherwise }\end{array}$ \\
\hline Size site & Number of students at the site \\
\hline Size school & Number of students of the school that the site is part of \\
\hline Size board & Number of schools on the board that the site is part of \\
\hline HAVO & Dummy with value 1 if site provides education at HAVO level and 0 otherwise \\
\hline $\mathrm{VMBO}_{\mathrm{GT}}$ & Dummy with value 1 if site provides education at $\mathrm{VMBO}_{\mathrm{GT}}$ level and 0 otherwise \\
\hline $\mathrm{VMBO}_{\mathrm{KA}}$ & Dummy with value 1 if site provides education at $\mathrm{VMBO}_{\mathrm{KA}}$ level and 0 otherwise \\
\hline $\mathrm{VMBO}_{\mathrm{BA}}$ & Dummy with value 1 if site provides education at $\mathrm{VMBO}_{\mathrm{BA}}$ level and 0 otherwise \\
\hline Girls & Share of girls at site \\
\hline Foreigners & Share of non-western foreigners at zip-code level \\
\hline Income & Income per inhabitant in thousands of euros at zip-code level \\
\hline Public & Dummy with value 1 if site is part of a public school and 0 otherwise \\
\hline Catholic & Dummy with value 1 if site has a Catholic denomination and 0 otherwise \\
\hline Protestant & Dummy with value 1 if site has a Protestant denomination and 0 otherwise \\
\hline Neutral & Dummy with value 1 if site has a neutral denomination and 0 otherwise \\
\hline Other & $\begin{array}{l}\text { Dummy with value } 1 \text { if site has a denomination other than public, Catholic, } \\
\text { Protestant or neutral and } 0 \text { otherwise }\end{array}$ \\
\hline
\end{tabular}

\section{References}

Aghion P, Bloom N, Blundell R, Griffith R, Howitt P (2005) Competition and innovation: an inverted-U relationship. Q J Econ 120(2):701-728

Barrow L (2002) School choice trough relocation: evidence from the Washington, D.C. area. J Public Econ 86(2):155-189

Bifulco R, Ladd HF (2006) The impacts of charter schools on student achievement: evidence from North Carolina. Educ Financ Policy 1(1):50-90

Chakrabarti R (2008) Can increasing private school participation and monetary loss in a voucher program affect public school performance? J Public Econ 92:1371-1393

Friedman M (1962) Capitalism and freedom. University of Chicago Press, Chicago 
Hanushek EA, Woessmann L (2011) How much do educational outcomes matter in OECD countries. Econ Policy 26(3):427-491

Hanushek EA, Kain JF, Rivkin SG, Branch GF (2007) Charter school quality and parental decision making with school choice. J Public Econ 91(5-6):823-848

Hoxby CM (2000) Does competition among public schools benefit students and taxpayers? Am Econ Rev 90(5):1209-1238

Hoxby CM (2007) Does competition among public schools benefit students and taxpayers? A reply. Am Econ Rev 97(5):2038-2055

Hoxby CM, Murarka S (2009) Charter schools in New York City: who enrolls and how they affect their students' achievement. NBER Working Paper No. 14852. NBER, Cambridge

Hoxby CM, Rockoff JE (2005) Findings from the City of Big Shoulders. Educ Next 5(4):52-58

Hsieh C-T, Urquiola M (2006) The effects of generalized school choice on achievement and stratification: evidence from Chile's voucher program. J Public Econ 90(8-9):1477-1503

Kossmann EH (1978) The Low Countries 1780-1940. Oxford University Press, Oxford

Lavy V (2010) Effects of free choice among public schools. Rev Econ Stud 77(3):1164-1191

Loeb S, Valant J, Kasman M (2011) Increasing choice in the markets for schools: recent reforms and their effects on student achievement. Natl Tax J 64(1):141-164

Maslowski R, Scheerens J, Luyten H (2007) The effect of school autonomy and school internal decentralization on students' reading literacy. Sch Eff Sch Improv 18(3):303-334

Rouse CE, Barrow L (2009) School vouchers and student achievements: recent evidence and remaining questions. Annu Rev Econ 1(1):17-42

Rothstein J (2007) Does competition among public schools benefit students and taxpayers? Comment. Am Econ Rev 90(5):2026-2037

Sandström M, Bergström F (2005) School vouchers in practice: competition will not hurt you. J Public Econ 89(2-3):351-380

Sass TR (2006) Charter schools and student achievement in Florida. Educ Financ Policy 1(1):91-122

West MR, Woessmann L (2009) Every catholic child in a catholic school: historical resistance to state schooling, contemporary private competition and student achievement. Econ J 116:C46-C62

Woessmann L (2009) Public private partnerships and student achievement: a cross-country analysis. In: Rajashri C, Peterson PE (eds) School choice international: exploring public-private partnerships. MIT Press, Cambridge, pp 13-45 